\title{
Efficacy of Bio NP Liquid Biofertilizer in Chilli Nursery
}

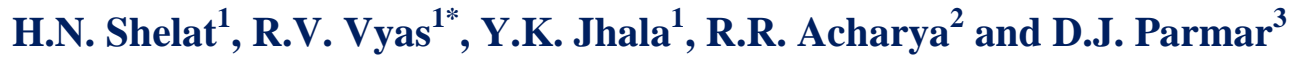 \\ ${ }^{1}$ Department of Agri. Microbiology, B. A. College of Agriculture, Anand Agricultural \\ University, Anand-388110, Gujarat, India \\ ${ }^{2}$ Main Vegetable Research Station, Anand Agricultural University, Anand-388110, \\ Gujarat, India \\ ${ }^{3}$ Department of Agri. Statistics, B. A. College of Agriculture, Anand Agricultural University, \\ Anand-388110, Gujarat, India \\ *Corresponding author
}

\section{A B S T R A C T}

\begin{tabular}{|l|}
\hline Ke y w or d s \\
NP liquid \\
Biofertilizer, \\
Chilli nursery. \\
\hline Article Info \\
\hline $\begin{array}{l}\text { Accepted: } \\
\text { 17 July } 2017 \\
\text { Available Online: } \\
\text { 10 September } 2017\end{array}$ \\
\hline
\end{tabular}

Keywords

NP liquid

Biofertilizer, Chilli nursery.

\section{Introduction}

Chilli (Capsicum annum L.) is the universal spice and is widely cultivated throughout temperate, tropical and subtropical countries. Being an important commercial crop, it finds diverse utilities as a spice, condiment, culinary supplement, medicine and vegetable. Chilli has two important commercial qualities, red color due to pigment capsanthin and biting pungency attributed by capsaicin. Indian chillies have been dominating international chilli market. Majority of chilli grown in India is cultivated in states such as Andhra Pradesh, Maharashtra, Karnataka,
Gujarat, Tamil Nadu and Orissa. India contributes one-fourth of the total quantity of chilli exported in the world. Its production level hovers around 1.1 million tonnes annually. Mineral nutrition is one of the main factors, which influences on growth, yield of chilli to a great extent. Continuous use of inorganic fertilizers has resulted in ecological imbalance with consequent ill effect on soil and environment. To maintain long term soil health and productivity there is a need for integrated nutrient management through manures and biofertilizers apart from costly 
chemical fertilizers for better yield of the crop (Mondal et al., 2003).Biofertilizers comprising of nitrogen fixing bacteria can fix atmospheric nitrogen whereas phosphate solubilizing organisms can solubilize phosphatic compounds and make phosphorous available to the plants. Among the nitrogen fixing bacteria, Azospirillum and Azotobacter, not only provides nitrogen, but also synthesizes growth promoting hormones such as IAA and GA, Azospirillum also helps in plant growth and increases the yield of crops by improving root development, mineral uptake etc. The positive role of these biofertilizers has been recorded in many vegetables and spice crops by different scientists. Hence, the present experiment was undertaken to study effect of nitrogen fixing and phosphate solubilizing bacteria on growth of seedlings of chilli $c v$. GVC 111 in nursery with the ultimate aim to provide healthy transplantable seedlings for raising the healthy crop.

\section{Materials and Methods}

The investigation was carried out at Department of agricultural Microbiology, B. A. College of Agriculture, Anand Agricultural University, Anand (Gujarat) during the period from kharif2011-14. The soil of experimental field was sandy loam having organic carbon content $0.25 \%$, available phosphorus $25.60 \mathrm{~kg} / \mathrm{ha}$, Nitrogen $0.025 \%$ and neutral $\mathrm{pH}$.The soil was well drained and retentive of moisture. It responded well to irrigation and manuring and was reasonably suitable for rice cultivation. The experiment was laid out in randomized block design with four replications and ten treatment combinations. The treatment combinations were: $\mathrm{T}_{1}$ Recommended NPK only (control), $\mathrm{T}_{2}-75 \%$ Recommended NPK only, $\mathrm{T}_{3^{-}} \quad 75 \%$ Recommended NPK + soil drenching of Azotobacter and PSB, $\mathrm{T}_{4}-75 \%$ Recommended NPK + soil drenching of
Azospirillum and PSB, $\mathrm{T}_{5^{-}} \quad 75 \%$ Recommended NPK + seed coating of Azotobacter and PSB, $\mathrm{T}_{6^{-}} \quad 75 \%$ Recommended NPK + seed coating of Azospirillum and PSB, $\mathrm{T}_{7-} \quad 75 \%$ Recommended NPK + soil drenching of Azotobacter and PSB+ foliar spray of Azotobacter and PSB at 15 DAS, $\mathrm{T}_{8^{-}} 75 \%$ Recommended NPK + soil drenching of Azospirillum and PSB+ foliar spray of Azospirillum and PSB at 15 DAS, $\mathrm{T}_{9^{-}} 75 \%$ Recommended NPK + seed coating of Azotobacter and PSB+ foliar spray of Azotobacter and PSB at 15 DAS, $\mathrm{T}_{10}-75 \%$ Recommended NPK + seed coating of Azospirillum and PSB+ foliar spray of Azospirillum and PSB at 15 DAS. The nursery was raised in $1 \mathrm{~m}^{2}$ beds. FYM was applied @ $000 \mathrm{~g} / \mathrm{m}^{2}$ to all the plots.

The experiment was repeated for three consecutive years at main vegetable research station farm at AAU, Anand. All the fertilizers were applied at the time of land preparation. The observations on germination percentage, root length, shoot length root and shoot fresh as well as dry weight and number of transplantable seedlings were recorded. The experimental data were pooled over three growing seasons and two locations followed by statistical analysis as per method suggested by Gomez and Gomez (1984).The microbiological observations include microbial population in soil and phyllosphere.

\section{Results and Discussion}

Results of pooled analysis (Table 1) of 3 years revealed that treatment $\mathrm{T}_{10}$ receiving 75 $\%$ RDF NP along with Azospirillum + PSB seed treatment before sowing followed by foliar application at 15 DAS was found statistically the highest for germination (91\%), root length (4.88), shoot length (11.83), root and shoot fresh weight (4.52 and $18.97 \mathrm{~g})$ as well as dry weight of root $(2.0 \mathrm{~g})$ 
shoot $(6.07 \mathrm{~g})$ and biomass $(8.07 \mathrm{~g})$ which was at par with $100 \%$ RDF NP.

Data analysis by FRBD as control vs. Rest (pooled over 3 years, Table 2) showed that among two biofertilizers treatments Azospirillum + PSB treatment was found significantly superior and Azotobacter + PSB treatment for root length and shoot fresh weight, whereas non-significant differences are observed for rest of the tested parameters. Among two methods of biofertilizers application i.e. seed treatment and soil drenching, seed treatment was found significantly superior over soil drenching of biofertilizers for all the parameters except root fresh and dry weight. Whereas foliar application of biofertilizers at 15DAI was found significantly superior over the treatments without foliar application for root and shoot length.

Economics presented in table 3 revealed that per $100 \mathrm{~m}^{2}$ highest gross income and BCR of Rs.18570and 2.26, respectively were obtained in $\mathrm{T}_{10}$ followed by $\mathrm{T}_{1}(18300,2.22)$.

Table.1 Growth parameters of Chilli as influenced by different treatments (Pooled over 3 years)

\begin{tabular}{|c|c|c|c|c|c|c|c|c|}
\hline \multirow[t]{2}{*}{ Tr No } & \multirow[t]{2}{*}{$\begin{array}{l}\text { Germination } \\
(\%)\end{array}$} & \multirow{2}{*}{$\begin{array}{l}\text { Root } \\
\text { length } \\
(\mathrm{cm})\end{array}$} & \multirow{2}{*}{$\begin{array}{l}\text { Shoot } \\
\text { length } \\
\text { (cm) }\end{array}$} & \multicolumn{2}{|c|}{$\begin{array}{c}\text { Fresh weight } \\
\text { (g) }\end{array}$} & \multicolumn{3}{|c|}{$\begin{array}{c}\text { Dry weight } \\
\text { (g) }\end{array}$} \\
\hline & & & & Root & Shoot & Root & Shoot & Biomass \\
\hline$T_{1}$ & $90^{\mathrm{ab}}$ & $4.46^{\mathrm{ab}}$ & $10.93^{\mathrm{ab}}$ & $4.38^{\mathrm{ab}}$ & $18.65^{\mathrm{a}}$ & $1.92^{\mathrm{ab}}$ & $5.63^{\mathrm{ab}}$ & $7.56^{\mathrm{ab}}$ \\
\hline $\mathbf{T}_{2}$ & $81^{\mathrm{d}}$ & $3.22^{\mathrm{d}}$ & $8.27^{\mathrm{d}}$ & $2.40^{\mathrm{c}}$ & $12.71^{\mathrm{c}}$ & $0.61^{\mathrm{c}}$ & $3.42^{\mathrm{d}}$ & $3.99^{\mathrm{d}}$ \\
\hline $\mathbf{T}_{3}$ & $84^{\mathrm{cd}}$ & $3.74^{\mathrm{cd}}$ & $9.61^{\mathrm{c}}$ & $3.16^{\mathrm{bc}}$ & $14.70^{\mathrm{bc}}$ & $1.13^{\mathrm{bc}}$ & $4.26^{\mathrm{cd}}$ & $5.39^{\mathrm{cd}}$ \\
\hline $\mathbf{T}_{4}$ & $85^{\mathrm{bcd}}$ & $3.95^{\mathrm{bc}}$ & $10.13^{b c}$ & $3.28^{\mathrm{abc}}$ & $15.35^{\mathrm{abc}}$ & $1.27^{\mathrm{abc}}$ & $4.50^{c}$ & $5.77^{\mathrm{c}}$ \\
\hline $\mathbf{T}_{5}$ & $85^{\mathrm{bcd}}$ & $4.00^{\mathrm{bc}}$ & $9.85^{\mathrm{c}}$ & $3.56^{\mathrm{abc}}$ & $16.32^{\mathrm{abc}}$ & $1.34^{\mathrm{abc}}$ & $4.69^{\mathrm{bc}}$ & $6.02^{\mathrm{bc}}$ \\
\hline$T_{6}$ & $87^{\mathrm{abc}}$ & $4.19^{\mathrm{bc}}$ & $10.31^{\mathrm{bc}}$ & $3.75^{\mathrm{ab}}$ & $17.40^{\mathrm{ab}}$ & $1.47^{\mathrm{ab}}$ & $4.89^{\mathrm{bc}}$ & $6.36^{\mathrm{bc}}$ \\
\hline $\mathbf{T}_{7}$ & $86^{\text {abcd }}$ & $4.28^{\mathrm{bc}}$ & $10.17^{b c}$ & $3.97^{\mathrm{ab}}$ & $17.53^{\mathrm{ab}}$ & $1.58^{\mathrm{ab}}$ & $5.04^{\mathrm{abc}}$ & $6.62^{\mathrm{abc}}$ \\
\hline$T_{8}$ & $88^{\mathrm{abc}}$ & $4.46^{\mathrm{ab}}$ & $10.95^{\mathrm{ab}}$ & $4.01^{\mathrm{ab}}$ & $17.63^{\mathrm{ab}}$ & $1.71^{\mathrm{ab}}$ & $5.18^{\mathrm{abc}}$ & $6.89^{\mathrm{abc}}$ \\
\hline $\mathbf{T}_{9}$ & $88^{\mathrm{abc}}$ & $4.45^{\mathrm{ab}}$ & $11.08^{\mathrm{ab}}$ & $4.29^{\mathrm{ab}}$ & $18.08^{\mathrm{ab}}$ & $1.89^{\mathrm{ab}}$ & $5.68^{\mathrm{ab}}$ & $7.58^{\mathrm{ab}}$ \\
\hline$T_{10}$ & $91^{\mathrm{a}}$ & $4.88^{\mathrm{a}}$ & $11.83^{\mathrm{a}}$ & $4.52^{\mathrm{a}}$ & $18.97^{\mathrm{a}}$ & $2.00^{\mathrm{a}}$ & $6.07^{\mathrm{a}}$ & $8.07^{\mathrm{a}}$ \\
\hline SEm \pm & 1.46 & 0.17 & 0.28 & 0.38 & 1.10 & 0.23 & 0.31 & 0.45 \\
\hline $\begin{array}{l}\text { C.D. T } \\
\text { at } 5 \%\end{array}$ & 4.34 & 0.51 & 0.83 & 1.14 & 3.27 & 0.69 & 0.92 & 1.33 \\
\hline $\begin{array}{l}\text { CD at } Y \\
\times \text { T } 5 \%\end{array}$ & 3.04 & 0.54 & 1.01 & 0.74 & 1.97 & 0.26 & 0.53 & 0.58 \\
\hline C.V. \% & 2.49 & 9.27 & 6.97 & 14.13 & 8.37 & 12.69 & 7.66 & 6.50 \\
\hline
\end{tabular}


Table.2 Growth parameters of Chilli as influenced by different treatments (Factorial RBD as Control Vs Rest)

\begin{tabular}{|c|c|c|c|c|c|c|c|c|}
\hline \multirow[t]{2}{*}{ Tr No } & \multirow{2}{*}{$\begin{array}{c}\text { Germination } \\
(\%)\end{array}$} & \multirow{2}{*}{\begin{tabular}{|c|} 
Root \\
length \\
$(\mathrm{cm})$
\end{tabular}} & \multirow{2}{*}{$\begin{array}{l}\text { Shoot } \\
\text { length } \\
(\mathrm{cm})\end{array}$} & \multicolumn{2}{|c|}{$\begin{array}{c}\text { Fresh weight } \\
\text { (g) }\end{array}$} & \multicolumn{3}{|c|}{$\begin{array}{l}\text { Dry weight } \\
\text { (g) }\end{array}$} \\
\hline & & & & Root & Shoot & Root & Shoot & Biomass \\
\hline \multicolumn{9}{|c|}{ EFFECT OF B (Biof) } \\
\hline B1 (Azoto+PSB) & 85.79 & 4.12 & 10.18 & 3.74 & 16.66 & 1.49 & 4.92 & 6.40 \\
\hline B2 (Azosp+PSB) & 87.87 & 4.37 & 10.80 & 3.84 & 17.34 & 1.61 & 5.16 & 6.77 \\
\hline SEm \pm & 1.13 & 0.06 & 0.24 & 0.26 & 0.21 & 0.8 & 0.05 & 0.13 \\
\hline C.D. at 5\% & NS & 0.17 & NS & NS & NS & NS & 0.15 & NS \\
\hline \multicolumn{9}{|c|}{ EFFECT OF M (Methods of biof application) } \\
\hline $\begin{array}{l}\text { M1 (SOIL } \\
\text { DRENCH) }\end{array}$ & 85.79 & 4.11 & 10.21 & 3.60 & 16.30 & 1.42 & 4.74 & 6.17 \\
\hline M2 (SEED) & 87.87 & 4.38 & 10.77 & 3.98 & 17.69 & 1.68 & 5.33 & 7.00 \\
\hline SEm \pm & 0.33 & 0.06 & 0.11 & 0.16 & 0.21 & 0.09 & 0.05 & 0.13 \\
\hline C.D. at 5\% & 0.93 & 0.17 & 0.31 & NS & 0.59 & NS & 0.15 & 0.79 \\
\hline \multicolumn{9}{|c|}{ EFFECT OF F (Foliar biof application) } \\
\hline $\begin{array}{l}\text { F1 (WITHOUT } \\
\text { FOLIAR) }\end{array}$ & 85.33 & 3.97 & 9.97 & 3.44 & 15.94 & 1.30 & 4.59 & 5.88 \\
\hline F2 (FOLIAR) & 88.33 & 4.52 & 11.01 & 4.14 & 18.05 & 1.79 & 4.49 & 7.29 \\
\hline $\mathrm{SEm} \pm$ & 096 & 0.06 & 0.11 & 0.08 & 0.98 & 0.18 & 0.22 & 0.34 \\
\hline C.D. at 5\% & $\mathrm{NS}$ & 0.17 & 0.31 & NS & $\mathrm{NS}$ & NS & $\mathrm{NS}$ & $\mathrm{NS}$ \\
\hline \multicolumn{9}{|l|}{ YEAR EFFECT } \\
\hline Y1 (2010-11) & 79.48 & 4.37 & 11.54 & 0.84 & 7.39 & 0.46 & 2.48 & 2.93 \\
\hline Y2 (2012-13) & 90.13 & 4.19 & 9.89 & 6.20 & 16.88 & 2.98 & 5.23 & 8.21 \\
\hline Y3 (2013-14) & 90.89 & 4.17 & 10.04 & 4.33 & 26.71 & 1.21 & 7.41 & 8.62 \\
\hline SEm \pm & 0.40 & 0.07 & 0.14 & 0.10 & 0.26 & 0.03 & 0.07 & 0.06 \\
\hline C.D. at 5\% & 1.14 & $\mathrm{NS}$ & 0.39 & 0.85 & 0.73 & 0.09 & 0.18 & 0.19 \\
\hline \multicolumn{9}{|c|}{ SIGNIFICANT INTERACTION } \\
\hline Y X B & 1.62 & - & - & - & - & 0.13 & & 0.27 \\
\hline Y X M & - & - & 0.55 & 0.14 & - & 0.13 & & 0.27 \\
\hline Y X F & 1.62 & - & - & 0.40 & 1.04 & 0.13 & 0.26 & 0.27 \\
\hline M XF & - & - & - & - & - & - & 0.21 & 0.23 \\
\hline CONT VS REST & 0.98 & 0.18 & 0.33 & 0.24 & 0.64 & 0.09 & 0.17 & 0.19 \\
\hline $\begin{array}{l}\text { Y X CON VS } \\
\text { REST }\end{array}$ & 3.04 & NS & 1.01 & 0.75 & 1.97 & 0.27 & 0.53 & 0.59 \\
\hline SEm \pm & 1.46 & 0.17 & 0.28 & 0.38 & 1.10 & 0.23 & 0.31 & 0.45 \\
\hline C.D. at 5\% & 4.34 & 0.51 & 0.83 & 1.14 & 3.27 & 0.69 & 0.92 & 1.33 \\
\hline C.V.\% & 2.49 & 9.27 & 6.97 & 14.13 & 8.37 & 12.69 & 7.66 & 6.50 \\
\hline
\end{tabular}


Table.3 Economics as influenced by different treatments

\begin{tabular}{|c|c|c|c|c|c|c|}
\hline \multirow{3}{*}{ Trt No } & \multirow{2}{*}{ TP seedling $/ \mathrm{m}^{2}$} & \multicolumn{4}{|c|}{ Per $100 \mathrm{~m}^{2}$} & \multirow[b]{2}{*}{ BCR } \\
\hline & & TP seedlings & Gross Income & Cult. cost & Net benefit & \\
\hline & No. & No & Rs. & Rs. & Rs. & \\
\hline $\mathrm{T}_{1}$ & 610 & 61000 & 18300 & 8249 & 10051 & 2.22 \\
\hline $\mathrm{T}_{2}$ & 506 & 50600 & 15180 & 8230 & 6950 & 1.84 \\
\hline $\mathrm{T}_{3}$ & 537 & 53700 & 16110 & 8232 & 7879 & 1.96 \\
\hline $\mathrm{T}_{4}$ & 547 & 54700 & 16410 & 8232 & 8179 & 1.99 \\
\hline $\mathrm{T}_{5}$ & 565 & 56500 & 16950 & 8231 & 8719 & 2.06 \\
\hline $\mathrm{T}_{6}$ & 575 & 57500 & 17250 & 8231 & 9019 & 2.10 \\
\hline $\mathrm{T}_{7}$ & 582 & 58200 & 17460 & 8235 & 9225 & 2.12 \\
\hline $\mathrm{T}_{8}$ & 590 & 59000 & 17700 & 8235 & 9465 & 2.15 \\
\hline $\mathrm{T}_{9}$ & 599 & 59900 & 17970 & 8234 & 9736 & 2.18 \\
\hline $\mathrm{T}_{10}$ & 619 & 61900 & 18570 & 8234 & 10336 & 2.26 \\
\hline
\end{tabular}

Indian chillies have been dominating international chilli market. Majority of chilli grown in India is cultivated in states such as Andhra Pradesh, Maharashtra, Karnataka, Gujarat, Tamil Nadu and Orissa. India contributes one-fourth of the total quantity of chilli exported in the world. Its production level hovers around 1.1 million tonnes annually. Biofertilizers Azotobacter, Azospirillum, PSB contribute significantly in vegetables. Seed as well as foliar application of biofertilizers Azotobacter, Azospirillum and PSB are reported by Farhad et al., (2012). The results of the present study clearly indicate the inoculation of the microbes were highly beneficial for enhancing the yield besides effecting a reduction in the cost of inorganic fertilizers and also significantly increases the soil fertility, soil beneficial microbes, and decreases the rate of diseases incidence.

From the foregoing results, it is concluded that treatment $\mathrm{T}_{10}$ wherein soil application of $75 \%$ RDF NP along with seed treatment @ $5 \mathrm{ml} / \mathrm{kg}$ OR soil application @ 1L/ha with Nitrogen fixer $A$. lipoferum ASA-1 together with Phosphate solubilizer B. coagulans PBA 16 , followed by foliar application @ 5ml/L water at 15 DAS had significant influence on number of transplantable seedlings and other seedling characters in chilli nursery.

The positive influence of biofertilizers on various growth parameters observed in the present study were due to enhanced uptake of nutrients by the plants (Borea, 1991). Azospirillum aid in increased plant growth due to their nitrogen fixing capacity and also they are known to help in the synthesis of growth promoting substances like IAA and GA (Jackson and Brown, 1966). The present findings are also in good agreement with the observations of Gowda et al., (2002) who observed the improved growth, yield and quality of chilli with $75 \%$ nitrogen, phosphorus plus $100 \%$ potassium in addition to the inoculation of biofertilizers.

Application of biofertilizers along with reduced levels of chemical fertilizers has beneficial effects compared to application of recommended NPK. PSB enhances $P$ availability, it is also known to produced amino acids, vitamins and growth promoting substances like IAA and GA, which help in better growth of plants. 


\section{References}

Borea, J.M., 1991. Vesicular arbuscularmycorrhizae as modifiers of soil fertility. Adv. soil sci. Springerverlag. New York, 15, 2-31.

Farhad, H., Ali, S., Hemmatollah, P., Seyyed, M. S., 2012. A comparison between foliar application and seed inoculation of biofertilizers on canola (Brassica napus L.) grown under waterlogged conditions. Aust. J. Crop Sci., 6(10), 1435-1440.

Gomez, K.A., and Gomez, A. A., 1984. Statistical Procedures for Agricultural Research ( $2^{\text {nd }}$ Ed.). A wiley Inter Science publication (John Wiley and Sons). New York. pp. 20-30.
Gowda, Kempe, K., Sajjan, M. and Sreeramm, B.S., 2002. Effect of biofertilizers with graded levels of nitrogen and phosphorus on growth, yield and quality of chillies (Capsicum annиитL.) cv. Byadagidabba. PLACROSYM, 15, 304-09.

Jackson, K.M., and Brown, M.E. 1966. Behaviour of Azotobacter chroococcum introduced in to the plant rhizospher. Ann. Inst. Pasteur. Paris. 3: 108-12.

Mondal, T., Ghanti, P., Mahato, B., Mondal, A. R. and Thapa, U., 2003. Effect of spacing and biofertilizer on yield and yield attributes of direct sown Chilli $(C$. annuum L. Cv. Bona Lanka). Env. Eco, 21, 712-15.

\section{How to cite this article:}

Shelat, H.N., R.V. Vyas, Y.K. Jhala, R.R. Acharya and Parmar, D.J. 2017. Efficacy of Bio NP Liquid Biofertilizer in Chilli Nursery. Int.J.Curr.Microbiol.App.Sci. 6(9): 1292-1297. doi: https://doi.org/10.20546/ijcmas.2017.609.155 